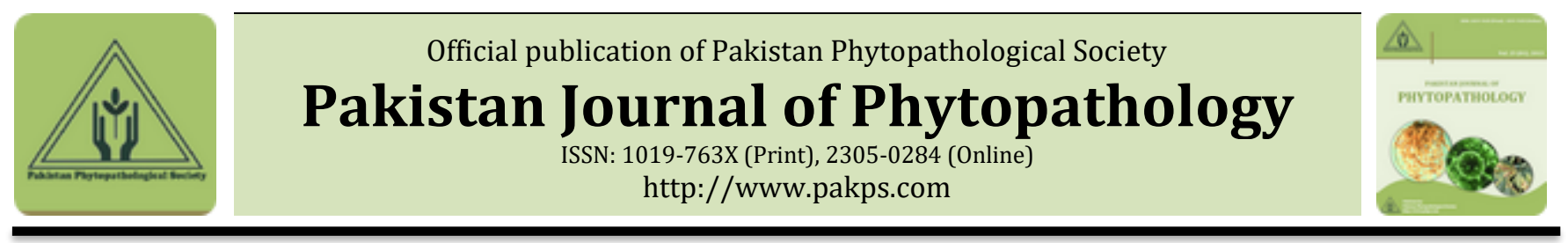

\title{
EVALUATION OF BOTANICALS AND FUNGICIDES AGAINST SEED BORNE FUNGI AND GERMINATION OF ROUGH LEMON SEEDS
}

\author{
a,bHaris Khalid*, aMuhammad J. Jaskani, bMuhammad Atiq, dSabir H. Khan, bNasir A. Rajput, eIrfan Ahmad, \\ aMuhammad Azam, cSaud Khalid \\ anstitute of Horticulture Sciences, University of Agriculture, Faisalabad, Pakistan. \\ ${ }^{b}$ Department of Plant Pathology, University of Agriculture, Faisalabad, Pakistan. \\ cSchool of Food Science and Engineering, South China University of Technology, Guangzhou, China \\ dInstitute of Plant Pathology, Ayub Agriculture Research Institute (AARI), Faisalabad, Pakistan. \\ eDepartment of Forestry and Range Management, University of Agriculture Faisalabad, Pakistan.
}

\section{A B S T R A C T}

Citrus fruits are grown all over the world, including Pakistan. However, the poor storage conditions for citrus seeds in tropical and sub-tropical regions compromise their viability during growth. In this study, M. olifera (Moringa) and $A$. niger (Neem) leaves were used as seed coating agents and were utilized for the first time without any deep treatment of such leaves with an objective to reduce the cost of botanical fungicides and to control the harmful effects of synthetic fungicides. Topsin- $\mathrm{M}$, a synthetic fungicide, was used as a reference compound to compare the results of fungicides from botanical sources than that of a traditionally available synthetic fungicide. Three different concentration of fungicide solutions (C1, C2 and C3), that were coated on the surface of seeds for different duration of time $(8,10$ and $12 \mathrm{~h})$, were prepared. It was observed that the coating of seeds with fungicides, either botanical or synthetic, significantly improved the horticultural (germination \%age and number of days required for germination) and pathological (fungi \%age and number of contaminated seeds) parameters of rough lemon, as compare to control or non-coated seed samples. It is expected that the findings of this study will promote the use of botanicals as seed coating agent as they are readily available to famers and are also acceptable for the cultivation of organic crops.

Keywords: Pre-sowing treatment, Seed coating, fungicide, Azaderachta indica, Citrus jambhiri, Moringa oleifera, Topsin-M.

\section{INTRODUCTION}

Citrus belongs to Rutaceae family. Tropical and subtropical climate are ideal for the growth of citrus fruit. The annual production of citrus crop, on global scale, was reported to be 124 million tones (FAO, 2017). Pakistan ranks 13 among the top citrus growing countries in the world. Over $95 \%$ of citrus is grown in Punjab province of Pakistan due to its favorable soil and optimum climatic conditions (Javeed, 2017). However, delayed seed germination severely affects the yield and quality of the citrus crop (Misra and Dwivedi, 2004).

\footnotetext{
Submitted: April 11, 2018

Revised: August 04, 2018

Accepted for Publication: October 24, 2018

* Corresponding Author:

Email: harisrhk@gmail.com

(c) 2017 Pak. J. Phytopathol. All rights reserved.
}

Actually, germination of seeds and the growth of citrus plant is affected by different biotic and abiotic factors including diseases, drought, salinity and insects-pests attack (Sarlikioti et al., 2010; Farooq et al., 2007). Furthermore, occurrence of any such factor hampers the productivity of citrus fruits (Kaur et al., 2005). Selection of good quality seeds could be helpful in controlling delayed seed germination and resisting harsh weather conditions.

Seed germination and emergence is the vital phase in plant's life. Furthermore, the selection of good quality seeds provide assurance for fast germination and better resistance against critical weather conditions (El-Keblawy and Al-Rawai, 2006). Pre-sowing seed treatments, either alone or in combination with other invigoration procedures, has been used successfully to improve the quality of seeds for several different crops (Basra et al., 
2002). On the other hand, citrus seeds belong to recalcitrant group that can't withstand freezing or drying temperature (Khan et al., 2003). Actually, the longevity of recalcitrant seeds depends on optimum storage conditions (i.e., ambient temperature and low moisture). However, the environmental conditions in tropical and sub-tropical regions are generally inferior for seed storage than that of temperate regions. Consequently, the maintenance of the viability of citrus seeds throughout the storage is usually a bigger issue in tropical and sub-tropical regions. Seed priming is another strategy widely employed for rapid germination of several crops (Farooq et al., 2007, 2008) under ideal as-well-as harsh environmental conditions (Nascimento, 2003; Sedghi et al., 2010). Numerous presowing seed treatment methods have been utilized till date including seed coating, seed priming and seed pelleting, etc. (Gamboa-de Buen et al., 2006; Capron et al., 2000). Compared to other priming and pelleting techniques, seed coating is used very often traditionally since it is convenient to use, readily available in the market and more economical than other techniques. In one of the previous study, it was observed that the deterioration of seed vigor reduced the germination percentage while coating with organic extracts and fungicides enhanced the invigoration of the low life seed lots (Selvarani et al., 2011).

The use of organic extracts has long been used as an attractive alternative to synthetic chemicals for pest management and disease resistance, since the organic compounds pose little threat to the environment or to human health. Several plant substances have been considered for use as insect anti-feedants or fungus repellents and can potentially limit the use of synthetic chemicals. It has been reported that the moringa leaves are rich in zeatin (El-Hamied and El-Amary, 2015) that promotes cell division and elongation; it can therefore potentially enhance the germination of citrus seeds. It has also been reported that the neem leaves are rich in nimonol (Mahmoud et al., 2011) that demonstrates toxic behavior against several fungal pathogens. However, the extraction of such compounds from botanical sources is an expensive treatment that limit the use of such botanical extracts. In this study, the neem and moringa leaves were ground to small particles and were used directly as pre-sowing treatment of citrus seeds for the first time, without any deep treatment, to reduce the cost of such priming agents. Topsin- $\mathrm{M}$, a traditional and synthetic fungicide, was utilized as a reference priming agent to compare the germination percentage and percentage of decayed seeds with that of botanical sources. It is expected that the findings of this study will promote the use of botanicals as seed coating agent as they are easily available to famers and are also acceptable for the cultivation of organic crops.

\section{MATERIALS AND METHODS}

Freshly harvested fruits of rough lemon (Citrus jambhiri) were collected from the Experimental Fruit Garden, Institute of Horticultural Sciences, University of Agriculture, Faisalabad, Pakistan. Topsin ${ }^{\circledR} M$ WSB Fungicide (denoted as Topsin-M in this work) of United Phosphorous Inc. (Pennsylvania, United States) was procured from the local market. Moringa (Moringa olifera) and Neem (Azadiractha indica) leaves were taken from Forestry Experiment Side of University of Agriculture Faisalabad, Pakistan. A small concentration of wood ash was kindly donated by a local bakery in Faisalabad, Pakistan.

Preparation of fungicide solutions: Figure 1 is showing the step by step guide that was followed to prepare samples. Initially, Moringa and Neem leaves were disintegrated into small particles using locally fabricated grinding machine. Disintegrated leaves were then stored in refrigerated conditions $\left(4^{\circ} \mathrm{C}\right)$ for $24 \mathrm{~h}$, followed by preparation of solutions at different concentrations $(25,50$ and $70 \%)$. Solution of Topsin-M was also prepared using three different concentrations $(1,2$ and $3 \%)$ to compare the results of botanical fungicides with that of synthetic fungicide. A small concentration of wood ash was added in all the solutions to ease the coating process.

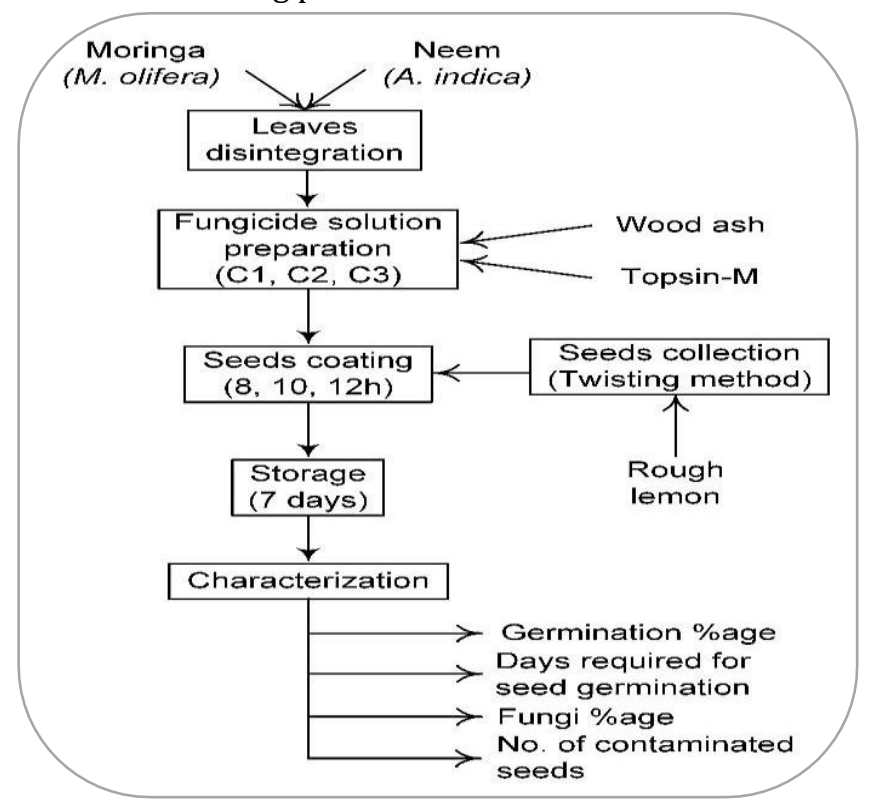

Figure 1. Flow line of sample preparation. 
Collection of seeds: Collection of seeds was carried out by twisting method. A cut was applied on the rind of rough lemon with the help of a knife that twisted the fruit. After dividing the fruit in two halves, seeds were collected manually with the help of hand. All the seeds were then stored in air tight bags and were stored under controlled conditions of temperature and humidity to avoid any probability of moisture uptake.

Coating of seeds and storage: The coating of seeds with different coating solutions was conducted in the inoculation room of Plant Tissue Culture Cell, University of Agriculture, Faisalabad. Initially, the inoculation chamber was sterilized with UV light. Later on, the seeds were dipped in coating for 8,10 and $12 \mathrm{~h}$. The seeds were then taken out from the solutions and were then placed in petri plate in growth room of Plant Tissue Culture Cell,

$$
\text { Percectage of contaminated seeds }=\frac{\text { No. of contaminated seeds }}{\text { Total number of seeds }} \times 100
$$

Germination of seeds: All the coated seeds were sown in germination trays and the trays were placed in the growth room of Plant Tissue Culture Cell, University of Agriculture, at room temperature. Germination percentage of seeds was calculated after 10 days of sowing the seeds using mentioned below formula, as proposed elsewhere (Khan et al., 2002).

$$
\begin{aligned}
& \text { Germination }(\%)=\frac{\text { No. of seeds germinated }}{\text { Total no. of seeds }} \times 100 \\
& \text { STATISTICAL ANALYSIS }
\end{aligned}
$$

\section{STATISTICAL ANALYSIS}

Five replicates of each treatment were studied using completely randomized design under factorial arrangement. Statistix 8.1 software was utilized to analyze the data. Analysis of variance was used to determine the significance of the data while least significance difference (LSD) was used to study the significance in the data.

\section{RESULTS AND DISCUSSION}

Table 1. Effect of interaction of botanicals and fungicides on percentage of fungi

\begin{tabular}{l|ccc|ccc|ccc}
\hline \multirow{2}{*}{ Treatments } & \multicolumn{9}{|c|}{ Percentage of fungi } \\
\cline { 2 - 11 } & \multicolumn{3}{|c|}{8 hours } & \multicolumn{3}{c|}{10 hours } & \multicolumn{3}{c}{12 hours } \\
\hline Conc. & C1 & C2 & C3 & C1 & C2 & C3 & C1 & C2 & C3 \\
\hline Control & $9.45 \mathrm{ab}$ & $9.75 \mathrm{a}$ & $9.24 \mathrm{~b}$ & $9.45 \mathrm{~b}$ & $9.75 \mathrm{a}$ & $9.24 \mathrm{c}$ & $9.45 \mathrm{~b}$ & $9.75 \mathrm{a}$ & $9.24 \mathrm{c}$ \\
\hline M. oleifera & $3.13 \mathrm{c}$ & $1.16 \mathrm{f}$ & $2.36 \mathrm{~d}$ & $3.28 \mathrm{e}$ & $3.10 \mathrm{f}$ & $4.14 \mathrm{~d}$ & $0.72 \mathrm{i}$ & $1.46 \mathrm{f}$ & $2.24 \mathrm{~d}$ \\
\hline A. indica & $2.83 \mathrm{c}$ & $1.15 \mathrm{f}$ & $1.59 \mathrm{e}$ & $1.24 \mathrm{j}$ & $2.27 \mathrm{~h}$ & $2.41 \mathrm{~g}$ & $0.56 \mathrm{j}$ & $1.13 \mathrm{~g}$ & $2.13 \mathrm{e}$ \\
\hline Topsin-M & $2.40 \mathrm{~d}$ & $1.02 \mathrm{f}$ & $0.22 \mathrm{~g}$ & $0.24 \mathrm{k}$ & $2.24 \mathrm{~h}$ & $1.36 \mathrm{i}$ & $0.25 \mathrm{k}$ & $1.06 \mathrm{~h}$ & $0.75 \mathrm{i}$ \\
\hline LSD & \multicolumn{3}{|c|}{0.3234} & \multicolumn{3}{c|}{0569} & & \multicolumn{3}{c}{0.0456} \\
\hline
\end{tabular}

${ }^{*}$ Mean values in a column sharing similar letters do not differ significantly as determined by the LSD test (P $\left.\leq 0.05\right)$.

M. oleifera $=(\mathrm{C} 1=25 \%, \mathrm{C} 2=50 \%$ and $\mathrm{C} 3=75 \%)$

A. indica $=(\mathrm{C} 1=25 \%, \mathrm{C} 2=50 \%$ and $\mathrm{C} 3=75 \%)$

Topsin- $\mathrm{M}=(\mathrm{C} 1=1 \mathrm{~g}, \mathrm{C} 2=2 \mathrm{~g}$ and $\mathrm{C} 3=3 \mathrm{~g})$
University of Agriculture, Faisalabad at room temperature for seven days to let them dry completely. Finally, the seeds were packed in air tight bags and were stored in the same growth room for seven days to check the incidence of contamination on seeds. On the other hand, non-coated seeds were also used as control to compare the results of different botanicals and fungicides used in this study.

Decaying of seeds: Treated rough lemon seeds that were stored in air-tight bags previously were examined under microscope after seven days of seed coating to check the incidence of fungal contamination on rough lemon seeds. Following formula was utilized to determine the percentage of contaminated seeds, as reported elsewhere (Zubbair, 2009).

Percentage of fungi: Table 1 is showing the effect of interaction between botanicals and fungicides on the percentage of fungi after seven days of storage in room temperature. Non-treated seeds showed the highest percentage of fungi. On the other hand, the coating of seeds significantly reduced the percentage of fungi, irrespective of the fungicide utilized to coat the seeds. Among all the fungicides utilized to coat the seeds, Topsin-M coated seeds expressed minimum percentage of fungi $(0.22 \%$ with $\mathrm{C} 3$ conc., $0.24 \%$ with $\mathrm{C} 1$ conc. and $0.25 \%$ with $\mathrm{C} 1$ conc. after 8 , 10 and $12 \mathrm{~h}$ of treatment, respectively) followed by $A$. indica coated seeds $(0.56 \%$ with $\mathrm{C} 1$ conc., $1.24 \%$ with $\mathrm{C} 1$ conc. and $1.15 \%$ with $\mathrm{C} 2$ conc. after 12,10 and $8 \mathrm{~h}$ of treatment, respectively) while $M$. oleifera coated seeds expressed maximum percentage of fungi ( $4.14 \%$ with C3 conc., $3.13 \%$ with C1 conc. and 2.24\% with C3 conc. after 10, 8 and 12h of treatment, respectively).

\section{Characterization}


observed that the non-coated seeds or control samples demonstrated least germination percentage. Coating of seeds significantly increased the germination percentage, irrespective of the fungicide used to coat the seeds. Topsin-M coated seeds exhibited maximum germination percentage $(99.37 \%$ with C2 conc., $98.46 \%$ with C3 conc. and $96.86 \%$ with C2 conc. after 10, 12 and
$8 \mathrm{~h}$ of treatment, respectively), followed by $A$. indica coated seeds $(97.72 \%$ with C1 conc., $96.67 \%$ with C1 conc. and $94.57 \%$ with C1 conc. after 10, 12 and $8 \mathrm{~h}$ of treatment respectively) and M. oleifera coated seeds expressed minimum germination percentage $197.67 \%$ with $\mathrm{C} 1$ conc., $96.34 \%$ with C3 conc. and $89.97 \%$ with C2 conc. after 10,12 and $8 \mathrm{~h}$ of treatment, respectively). Table 2. Effect of interaction between botanicals and fungicides on germination percentage of rough lemon seeds

\begin{tabular}{|c|c|c|c|c|c|c|c|c|c|}
\hline \multirow{3}{*}{$\begin{array}{l}\text { Treatments } \\
\text { Conc. }\end{array}$} & \multicolumn{9}{|c|}{ Germination percentage } \\
\hline & \multicolumn{3}{|c|}{8 hour } & \multicolumn{3}{|c|}{10 hour } & \multicolumn{3}{|c|}{12 hour } \\
\hline & $\mathrm{C} 1$ & $\mathrm{C} 2$ & C3 & $\mathrm{C} 1$ & $\mathrm{C} 2$ & C3 & C1 & $\mathrm{C} 2$ & C3 \\
\hline Control & 50.021 & $50.36 \mathrm{k}$ & $50.57 \mathrm{j}$ & 50.021 & $50.36 \mathrm{k}$ & $50.55 \mathrm{j}$ & 50.021 & $50.36 \mathrm{k}$ & $50.55 \mathrm{j}$ \\
\hline M. oleifera & $88.87 \mathrm{~h}$ & $89.97 \mathrm{~g}$ & $87.94 \mathrm{i}$ & $97.67 \mathrm{e}$ & $96.65 \mathrm{~h}$ & $96.84 \mathrm{~g}$ & $95.33 \mathrm{~h}$ & $94.35 \mathrm{i}$ & $96.34 \mathrm{f}$ \\
\hline A. indica & $94.57 \mathrm{~d}$ & $94.26 \mathrm{e}$ & $93.46 \mathrm{f}$ & $97.72 \mathrm{~d}$ & $95.36 \mathrm{i}$ & $97.42 \mathrm{f}$ & $96.67 \mathrm{~d}$ & $96.41 \mathrm{e}$ & $95.66 \mathrm{~g}$ \\
\hline Topsin-M & $96.23 \mathrm{~b}$ & $96.86 \mathrm{a}$ & $95.55 \mathrm{c}$ & $98.42 \mathrm{c}$ & $99.37 \mathrm{a}$ & $98.75 \mathrm{~b}$ & $97.35 \mathrm{c}$ & $97.68 \mathrm{~b}$ & $98.46 \mathrm{a}$ \\
\hline LSD & & 0.0424 & & & 0.0338 & & & 0.0418 & \\
\hline
\end{tabular}

*Mean values in a column sharing similar letters do not differ significantly as determined by the LSD test $(\mathrm{P} \leq 0.05)$.

M. oleifera $=(\mathrm{C} 1=25 \%, \mathrm{C} 2=50 \%$ and $\mathrm{C} 3=75 \%)$

A. indica $=(\mathrm{C} 1=25 \%, \mathrm{C} 2=50 \%$ and $\mathrm{C} 3=75 \%)$

Topsin- $\mathrm{M}=(\mathrm{C} 1=1 \mathrm{~g}, \mathrm{C} 2=2 \mathrm{~g}$ and $\mathrm{C} 3=3 \mathrm{~g})$

Days required for seed germination: Table 3 is showing the effect of interaction between botanicals and fungicides on the number of days required for germination of rough lemon seeds. It was observed that the non-coated seeds or control samples required maximum number of days to germinate. Coating of seeds reduced the number of days required for germination of seeds. Topsin-M coated seeds germinated in least number of days (15.68 days with C3 conc., 16.16 days with C2 conc. and 20.04 days with C3 conc. after 8, 10 and $12 \mathrm{~h}$ of treatment, respectively), followed by $A$. indica treated seeds (16.91 days with C1 conc., 17.79 days with C1 conc. and 23.57 days with c 3 conc. after 10,8 and $12 \mathrm{~h}$ of treatment, respectively) and M. oleifera treated seeds (27.56 days with C3 conc., 19.42 days with $\mathrm{C} 2$ conc. and 18.95 days with C2 conc. after 12, 8 and $10 \mathrm{~h}$ of treatment, respectively).

Table 3. Effect of interaction between botanicals and fungicides on days required for germination of rough lemon seeds

\begin{tabular}{l|ccc|ccc|ccc}
\hline \multirow{2}{*}{ Treatments } & \multicolumn{9}{|c|}{ Days to seed germination } \\
\cline { 2 - 11 } & \multicolumn{3}{|c}{8 hour } & \multicolumn{3}{c|}{10 hour } & \multicolumn{3}{c}{12 hour } \\
\hline Conc. & C1 & C2 & C3 & C1 & C2 & C3 & C1 & C2 & C3 \\
\hline Control & $28.68 \mathrm{a}$ & $28.15 \mathrm{c}$ & $28.36 \mathrm{~b}$ & $28.68 \mathrm{a}$ & $28.15 \mathrm{c}$ & $28.36 \mathrm{~b}$ & $28.68 \mathrm{a}$ & $28.15 \mathrm{c}$ & $28.36 \mathrm{~b}$ \\
\hline M. oleifera & $18.93 \mathrm{e}$ & $19.42 \mathrm{~d}$ & $15.76 \mathrm{j}$ & $17.41 \mathrm{~h}$ & $18.95 \mathrm{~d}$ & $18.56 \mathrm{f}$ & $26.69 \mathrm{e}$ & $25.47 \mathrm{f}$ & $27.56 \mathrm{~d}$ \\
\hline A. indica & $17.79 \mathrm{~g}$ & $17.84 \mathrm{f}$ & $17.96 \mathrm{f}$ & $16.91 \mathrm{j}$ & $17.85 \mathrm{~g}$ & $18.68 \mathrm{e}$ & $25.34 \mathrm{~g}$ & $24.13 \mathrm{~h}$ & $23.57 \mathrm{i}$ \\
\hline Topsin-M & $16.67 \mathrm{i}$ & $16.75 \mathrm{~h}$ & $15.68 \mathrm{k}$ & $16.70 \mathrm{k}$ & $16.16 \mathrm{l}$ & $17.00 \mathrm{i}$ & $22.24 \mathrm{j}$ & $21.13 \mathrm{k}$ & $20.04 \mathrm{l}$ \\
\hline LSD & \multicolumn{4}{|c|}{0.0588} & & & 0.0334 & & \multicolumn{3}{c}{0.0404} \\
\hline
\end{tabular}

${ }^{*}$ Mean values in a column sharing similar letters do not differ significantly as determined by the LSD test (P $\left.\leq 0.05\right)$.

M. oleifera $=(\mathrm{C} 1=25 \%, \mathrm{C} 2=50 \%$ and $\mathrm{C} 3=75 \%)$

A. indica $=(\mathrm{C} 1=25 \%, \mathrm{C} 2=50 \%$ and $\mathrm{C} 3=75 \%)$

Topsin- $\mathrm{M}=(\mathrm{C} 1=1 \mathrm{~g}, \mathrm{C} 2=2 \mathrm{~g}$ and $\mathrm{C} 3=3 \mathrm{~g})$

Number of contaminated seeds: Rough lemon seeds were examined under optical microscope to identify the seed-borne fungi that contaminated rough lemon seeds during storage period. Seeds that showed the incidence of fungi were donated as contaminated seeds. Rest of the seeds were donated as healthy seeds. Following four fungi were mainly detected under microscope on the surface of contaminated seeds: (a)
Aspergillus flavus; (b) Aspergillus niger; (c) Rhizophus stolonifera; and (d) Alternaria alternate. Table 4 is showing the effect of interaction between botanicals and fungicides on the number of contaminated seeds after seven days of storage in room temperature. Highest number of contaminated seeds were observed in case of non-coated seeds or control samples. Topsin$\mathrm{M}$ coated seeds were found to be least contaminated with fungi $(0.16 \%$ with $\mathrm{C} 2$ conc., $0.38 \%$ with $\mathrm{C} 1$ conc. and $1.00 \%$ with $\mathrm{C} 1$ conc. after 12,8 and $10 \mathrm{~h}$ of treatment, respectively) followed by $A$. indica coated 
seeds $(0.43 \%$ with C2 conc., $0.83 \%$ with C3 conc. and $1.23 \%$ with C3 conc. after 12, 8 and $10 \mathrm{~h}$ of treatment, respectively) M. oleifera coated seeds had maximum Table 4. Effect of interaction between botanicals and fungicides on number of contaminated seeds of rough lemon seeds after seven days of storage in room temperature.

\begin{tabular}{|c|c|c|c|c|c|c|c|c|c|}
\hline \multirow{3}{*}{$\begin{array}{l}\text { Treatments } \\
\text { Conc. }\end{array}$} & \multicolumn{9}{|c|}{ Number of contaminated seeds } \\
\hline & \multicolumn{3}{|c|}{8 hours } & \multicolumn{3}{|c|}{10 hours } & \multicolumn{3}{|c|}{12 hours } \\
\hline & C1 & $\mathrm{C} 2$ & C3 & C1 & $\mathrm{C} 2$ & C3 & C1 & $\mathrm{C} 2$ & C3 \\
\hline Control & $3.22 \mathrm{a}$ & $3.44 \mathrm{a}$ & $3.86 \mathrm{a}$ & $3.22 \mathrm{abc}$ & $3.44 \mathrm{ab}$ & $3.86 \mathrm{a}$ & $3.22 \mathrm{~b}$ & $3.44 \mathrm{ab}$ & $3.86 \mathrm{a}$ \\
\hline M. oleifera & $1.00 \mathrm{~b}$ & $1.13 \mathrm{~b}$ & $1.50 \mathrm{~b}$ & $2.16 \mathrm{bcd}$ & $2.23 \mathrm{bcd}$ & $1.80 \mathrm{~cd}$ & $2.24 \mathrm{c}$ & $1.54 \mathrm{de}$ & $2.46 \mathrm{c}$ \\
\hline A. indica & $0.83 \mathrm{~b}$ & $1.03 \mathrm{~b}$ & $0.83 \mathrm{~b}$ & $1.33 \mathrm{~d}$ & $2.13 \mathrm{bcd}$ & $1.23 \mathrm{~d}$ & $1.10 \mathrm{e}$ & $0.43 \mathrm{fg}$ & $2.14 \mathrm{~cd}$ \\
\hline Topsin-M & $0.38 \mathrm{~b}$ & $0.83 \mathrm{~b}$ & $0.733 \mathrm{~b}$ & $1.00 \mathrm{~d}$ & $1.70 \mathrm{~cd}$ & $1.00 \mathrm{~d}$ & 0.96 ef & $0.16 \mathrm{~g}$ & $1.29 \mathrm{e}$ \\
\hline LSD & \multicolumn{3}{|c|}{1.1679} & \multicolumn{3}{|c|}{1.5949} & \multicolumn{3}{|c|}{0.6207} \\
\hline
\end{tabular}

*Mean values in a column sharing similar letters do not differ significantly as determined by the LSD test (P $\leq 0.05)$.

M. oleifera $=(\mathrm{C} 1=25 \%, \mathrm{C} 2=50 \%$ and $\mathrm{C} 3=75 \%)$

A. indica $=(\mathrm{C} 1=25 \%, \mathrm{C} 2=50 \%$ and $\mathrm{C} 3=75 \%)$

Topsin $-\mathrm{M}=(\mathrm{C} 1=1 \mathrm{~g}, \mathrm{C} 2=2 \mathrm{~g}$ and $\mathrm{C} 3=3 \mathrm{~g})$

\section{DISCUSSION}

Percentage of fungi and contaminated seeds: In this work, we studied two different pathological parameters (i.e., fungi percentage and number of contaminated seeds) and found that the coating of seeds with fungicides, either botanical or synthetic, significantly reduced the number of contaminated seeds and fungi percentage during storage. For example, the number of contaminated seeds after $12 \mathrm{~h}$ of $\mathrm{C} 2$ treatment were found to be $0.16,0.43$ and $1.54 \%$ for Topsin-M, $A$. indica and $M$. olefera coated seeds, respectively, that were significantly less than that of control or non-coated samples (3.86\%). Similarly, the percentage of fungi after $10 \mathrm{~h}$ of C3 treatment were found to be 1.36, 2.41 and $4.14 \%$ for Topsin-M, A. indica and M. olefera coated seeds, respectively, that were significantly less than that of control samples (9.24\%). The findings of this study suggested that the coating of seeds with fungicides, either botanical or synthetic, can be used as a viable strategy to protect the seeds from fungal attack. The low-quality seeds are at risk to various types of diseases and require any kind of seed treatment to survive (Howell, 2007). Coating of seeds with fungicides cover the sensitive sites of such seeds and protects them from pathogen attack by releasing the fungicides on those sites of the seeds that are attacked by pathogens (Kibinza et al., 2011). Generally, the coating of seeds with Topsin-M was found to be more efficient in resisting the growth of fungi and decaying of seeds than that of fungicides from botanical sources. This was expected since the mode of action for synthetic number of contaminated seeds $2.46 \%$ with C3 conc., $2.23 \%$ with C2 conc. and $1.50 \%$ with C3 conc. after 12 , 10 and $8 \mathrm{~h}$ of treatment, respectively). fungicides is faster than that of botanical fungicides (Nascimento, 2003). Findings of our research fits well with previous studies whereby the coating of Cleoptra mandrin or Rangpur lime seeds with soybean leaf extract and sorghum leaf extract significantly improved the resistance of seeds against pathogen attack during storage (Rehman et al., 2012; Gade, 2012; Armarkar, 2011). It should be noted here that the botanical fungicides that we utilized in our study were taken directly from botanical sources, without any further purification to extract fungicidal compound of interest, in order to reduce the cost of such fungicides. Furthermore, the botanical fungicides used in our study demonstrated reasonably good control against seed borne pathogens. Mahmood and Sheikh (2006) observed that the retention of chemical fungicides is less for flat surfaced seeds than that of uneven or rough surfaced seeds. This shows that the efficiency of botanicals against pathogens might get lost slightly due to smooth surface of rough lemon seeds. It can be concluded therefore that the botanical fungicides can also be used as an alternative to synthetic fungicides to control the growth of seed borne fungi or pathogen attack during storage of rough lemon seeds. It is expected that the efficiency of such non-purified botanical fungicides can be enhanced with the combined use of 2 or more fungicides from different botanical sources. Further studies are therefore required in this area with an objective to enhance the efficiency of such fungicides against pathogen attack.

Germination percentage and days required for seed germination: Several seed treatment practices have been reported to improve the germination of seeds. In this study, it was observed that the seed coating method 
momentously improved seed germination and plant strength. For example, the germination percentage of rough lemon seeds after $10 \mathrm{~h}$ of C3 treatment were found to be $98.75,97.42$ and $96.84 \%$ for Topsin-M, A. niger and $M$. olifera treated seeds, respectively, that were significantly higher that of control (50.55\%). Similarly, the number of days required for germination of rough lemon seeds after $10 \mathrm{~h}$ of $\mathrm{C} 2$ treatment were found to be 16.16, 17.85 and 18.95 days for Topsin-M, A. niger and $M$. olifera treated seeds, respectively, that were significantly less than that of control or non-treated samples (28.15 days). However, the synthetic fungicide that exhibited fast releasing action demonstrated significantly different results than that of botanical fungicides. The reduction in germination time was because of short lag phase during imbibition that enabled seeds to germinate more quickly and germination process was found to be shorter for treated seeds because of the approachability of readily accessible food during germination (Farooq et al., 2009). In another study, improved germination time was attributed to improved cell division inside the apical meristem. The treating agent binds to nearby soil during sowing that provides pathogen free media to speed up the growth of plant cells (Vanangamudi et al., 2000). The findings of our research agree with previous reports whereby moringa leaf extracts and sesame leaf extracts were found to be effective in terms of reducing germination time for sorghum seeds (Shehzad et al., 2012) and onion seeds (Zenab and Inallou, 2011), respectively.

\section{CONCLUSION}

The findings of this study suggested that the coating of rough lemon seeds with fungicides, either synthetic or botanical, significantly improve the horticultural (germination \%age and number of days required for germination) and pathological (fungi \%age and number of contaminated seeds) parameters of the seeds during growth. For example, the number of contaminated seeds after $12 \mathrm{~h}$ of $\mathrm{C} 2$ treatment were found to be $0.16,0.43$ and $1.54 \%$ for Topsin-M, A. indica and M. olefera coated seeds, respectively, that were significantly less than that of control or non-coated samples (3.86\%). Similarly, the percentage of fungi after $10 \mathrm{~h}$ of $\mathrm{C} 3$ treatment were found to be 1.36, 2.41 and $4.14 \%$ for Topsin-M, $A$. indica and $M$. olefera coated seeds, respectively, that were significantly less than that of control samples (9.24\%). Likewise, the germination percentage of rough lemon seeds after $10 \mathrm{~h}$ of C3 treatment were found to be 98.75 , 97.42 and $96.84 \%$ for Topsin-M, A. niger and M. olifera treated seeds, respectively, that were significantly higher that of control (50.55\%). Similarly, the number of days required for germination of rough lemon seeds after $10 \mathrm{~h}$ of C2 treatment were found to be 16.16, 17.85 and 18.95 days for Topsin-M, A. niger and M. olifera treated seeds, respectively, that were significantly less than that of control or non-treated samples (28.15 days). It can be concluded therefore that the fungicides from botanical sources can be used as a suitable alternate to synthetic fungicides for the coating of rough lemon seeds. The findings of this study would encourage the use of fungicides from botanical sources without any deep treatment of such fungicides.

\section{ACKNOWLEDGEMENT}

Haris Khalid would like to acknowledge the support provided by Punjab Educational Endowment Fund (PEEF) for his Master studies at University of Agriculture Faisalabad.

\section{REFERENCES}

FAO. 2017. Production year book. Food and Agricultural Organization of the United Nations, Rome.

Abdul, R. 2012. Toxin production by Fusarium solani from declining citrus plants and its management. African Journal of Biotechnology, 11.

Armarkar, S. 2011. Role of Pseudomonas fluorescens and bioagents in management of root rot collar rot and growth response in citrus root stock. Ph. D. Thesis (Unpub.) Dr. PDKV, Akola.

Basra, S., M. Zia, T. Mehmood, I. Afzal and A. Khaliq. 2002. Comparison of different invigoration techniques in wheat (Triticum aestivum L.) seeds. Pakistan Journal of Arid Agriculture, Pakistan.

Capron, I., F. Corbineau, F. Dacher, C. Job, D. Côme and D. Job. 2000. Sugarbeet seed priming: effects of priming conditions on germination, solubilization of 11-S globulin and accumulation of LEA proteins. Seed Science Research, 10: 243-254.

El-Hamied, S. A. A. and E. I. El-Amary. 2015. Improving growth and productivity of "pear"trees using some natural plants extracts under north sinai conditions. IOSR Journal of Agriculture and Veterinary Science, 8: 1-9.

El-Keblawy, A. and A. Al-Rawai. 2006. Effects of seed maturation time and dry storage on light and temperature requirements during germination in invasive Prosopis juliflora. Flora - Morphology, 
Distribution, Functional Ecology of Plants, 201: 135-143.

Farooq, M., T. Aziz, A. Wahid, D.-J. Lee and K. H. M. Siddique. 2009. Chilling tolerance in maize agronomic and physiological approaches. Crop and Pasture Science, 60: 501.

Farooq, M., S. M. Basra, M. Hussain, H. Rehman and B. Saleem. 2007. Incorporation of polyamines in the priming media enhances the germination and early seedling growth in hybrid sunflower Helianthus annuus L. International Journal of Agriculture and Biology, 9: 868-872.

Farooq, M., S. M. A. Basra, I. Afzal and A. Khaliq. 2006. Optimization of hydropriming techniques for rice seed invigoration. Seed Science and Technology, 34: 507-512.

Farooq, M., S. M. A. Basra, H. Rehman and M. Hussain. 2008. Seed Priming with Polyamines Improves the Germination and Early Seedling Growth in Fine Rice. Journal of New Seeds, 9: 145-155.

Gade, R. 2012. Biological and chemical management of Phytophthora root rot/collar rot in citrus nursery. The BIOSCAN, 7: 631-635.

Gamboa-deBuen, A., R. Cruz-Ortega, E. Martínez-Barajas, M. E. Sánchez-Coronado and A. Orozco-Segovia. 2006. Natural priming as an important metabolic event in the life history of Wigandia urens (Hydrophyllaceae) seeds. Physiologia Plantarum, 128: 520-530.

Howell, C. R. 2007. Effect of Seed Quality and Combination Fungicide-Trichoderma spp. Seed treatments on pre- and postemergence dampingoff in cotton. Phytopathology, 97: 66-71.

I. El -Desouky, M. and S. A. A. El- Hamied. 2014. Improving growth and productivity of pomegranate fruit trees planted on sandy dunes slopes at Baloza district (N. Sinai) Using different methods of drip irrigation, organic fertilization, and soil mulching. IOSR Journal of Agriculture and Veterinary Science, 7: 86-97.

javeed, M. A. 2017. Fruits, vegetables and condiments statistics of Pakistan. Ministry of National Food Security and Research, Islamabad, Pakistan, pp. 12.

Kaur, S., A. K. Gupta and N. Kaur. 2005. Seed priming increases crop yield possibly by modulating enzymes of sucrose metabolism in chickpea. Journal of Agronomy and Crop Science, 191: 81-
87.

Khan, M. M., M. A. Alam, M. Abbas and M. J. Iqbal. 2003. Studies on seed desiccation tolerance in four citrus species. Pakistan Journal of Agriculture Sciences, 40: 55-62.

Khan, M. M., K. Thompson, M. Usman and B. Fatima. 2002. Role of moisture content and controlled atmosphere in citrus seed storage. International Journal of Agriculture and Biology, 4: 259-266.

Kibinza, S., J. Bazin, C. Bailly, J. M. Farrant, F. Corbineau and H. El-Maarouf-Bouteau. 2011. Catalase is a key enzyme in seed recovery from ageing during priming. Plant Science, 181: 309-315.

Mahmood, M. A. and A. Sheikh. 2006. Citrus export system in Pakistan. Journal of Agriculture Research, 44: 229-238.

Mahmoud, D. A., N. M. Hassanein, K. A. Youssef and M. A. Abou Zeid. 2011. Antifungal activity of different neem leaf extracts and the nimonol against some important human pathogens. Brazilian Journal of Microbiology, 42: 1007-1016.

Misra, N. and U. Dwivedi. 2004. Genotypic difference in salinity tolerance of green gram cultivars. Plant Science, 166: 1135-1142.

Nascimento, W. M. 2003. Muskmelon seed germination and seedling development in response to seed priming. Scientia Agricola, 60: 71-75.

R Ramjegathesh, S. V. 2014. Bio control potential of Pseudomonas fluorescens against Coleus root rot disease. Journal of Plant Pathology \& Microbiology, 05.

Rehman, A., N. Javed, A. U. Malik and S. Mehboob. 2012. Toxin production by Fusarium solani from declining citrus plants and its management. African Journal of Biotechnology, 11: 2199-2203.

Sarlikioti, V., S. M. Driever and L. F. M. Marcelis. 2010. Photochemical reflectance index as a mean of monitoring early water stress. Annals of Applied Biology, 157: 81-89.

Sedghi, M., A. Nemati and B. Esmaielpour. 2010. Effect of seed priming on germination and seedling growth of two medicinal plants under salinity. Emirates Journal of Food and Agriculture, 22: 130.

Selvarani, K. and R. Umarani. 2011. Evaluation of seed priming methods to improve seed vigour of onion Allium cepa cv. aggregatum and carrot Daucus carota. Journal of Agricultural Technology, 7: 857867. 
Shehzad, M., M. Ayub, A. Ahmad and M. Yaseen. 2012. Influence of priming techniques on emergence and seedling growth of forage sorghum Sorghum bicolor L. Journal of Animals and Plant Science, 22: 154-158.

Vanangamudi, K., M. Vanangamudi, A. Venkatesh, R. V. Rai, R. Umarani and S. Balaji. 2000. Effect of osmotic priming on seed germination and vigour of neem Azadirachta indica. Journal of Tropical
Forest Science, 12: 181-184.

Zeinab, A. a. M. M. I. 2011. Hydropriming influence on seedling vigour in rosemary Rosmarinus officinalis L. Journal of Fishries and Hydrobiology, 6: 491494.

Zubbair, N. A. 2009. Studies on nutritional requirement of Colletotrochum habisci (Tracy \& Earle.). International Journal of Advanced Biotechnology and Research, 1: 55-61. 